University of Pennsylvania Carey Law School

Penn Law: Legal Scholarship Repository

Faculty Scholarship at Penn Law

8-1-2005

\title{
The Promise and Limits of Voluntary Management - Based Regulatory Reform: An Analysis of EPA's Strategic Goals Program
}

Jason S. Johnston

University of Pennsylvania Carey Law School

Follow this and additional works at: https://scholarship.law.upenn.edu/faculty_scholarship

Part of the Administrative Law Commons, and the Environmental Law Commons

\section{Repository Citation}

Johnston, Jason S., "The Promise and Limits of Voluntary Management - Based Regulatory Reform: An Analysis of EPA's Strategic Goals Program" (2005). Faculty Scholarship at Penn Law. 68.

https://scholarship.law.upenn.edu/faculty_scholarship/68

This Article is brought to you for free and open access by Penn Law: Legal Scholarship Repository. It has been accepted for inclusion in Faculty Scholarship at Penn Law by an authorized administrator of Penn Law: Legal Scholarship Repository. For more information, please contact PennlawIR@law.upenn.edu. 


\title{
The Promise and Limits of Voluntary Management-Based Regulatory Reform: An Analysis of EPA's Strategic Goals Program
}

\author{
Jason Scott Johnston ${ }^{*}$
}

Although accounting for only a small share of American economy, the metal finishing industry has had a profound impact on the natural environment. The metal finishing industry supplies parts that are essential in products ranging from automobiles and household appliances to aircraft and military hardware. At the same time, metal finishing generates wastes from solvents, cleansers, and metal-ion-bearing aqueous solutions used for plating (such as hexavalent chromium, copper, gold and cadmium). Acid from finishing cleaners is found in metal finishing wastewater, and solvents may also be emitted into the air or disposed of in solid form. Many hazardous waste sites that were once solid waste landfills include contaminants from metal finishing wastes. It is fair to say that metal finishing is an industry whose environmental impact may far exceed its economic significance.

American environmental laws and regulations were drafted with an acute awareness of the metal finishing industry's potential environmental impact. The industry

\footnotetext{
* Kalpana Kotagal, Penn Law '05, provided exceptionally helpful research assistance on this project. I am grateful to Jay Benforado and Christian Richter for exceptionally helpful comments made at the conference where the initial draft of this paper was presented, to Jeffrey Smith for comments on an earlier draft, and to the editors for their extensive and careful work on this entire project. I am also grateful to the large number of EPA, state environmental and local POTW officials who took the time to talk to me about the Strategic Goals Program. I am of course solely responsible for any remaining errors.
} 
is subject to regulation under virtually every federal environmental statute. There is, moreover, substantial evidence that the traditional environmental regulatory regime in the United States has indeed succeeded in vastly improving the metal finishing industry's environmental performance.

The industrial structure of the metal finishing industry, however, places inherent limits on the ability of government to use traditional regulatory tools to improve the industry's environmental performance. The metal finishing industry is comprised of thousands of small firms, many of which are independent job shops that use a wide variety of metals in finishing a wide variety of products. The industry is geographically concentrated in the most heavily industrialized, and heavily polluted, states. Yet despite economies in being located close to their manufacturing clients, labor and raw materials costs in countries such as China are so low relative to U.S. levels that metal finishing is increasingly being shifted outside the U.S. Metal finishers have faced increasingly intense foreign competition, and a significant fraction of firms in the metal finishing industry operate on relatively thin profit margins and are not highly capitalized.

For purposes of regulatory policy, the significance of metal finishing is not that it is an industry where command and control environmental regulation failed. The evidence, discussed in more detail below, is that command and control regulation has driven metal finishers to either dramatically improve their environmental performance, or else shut down. Metal finishing is significant because the industry squarely raises the fundamental regulatory challenge of how to create incentives for continuing and yet increasingly costly environmental improvement in an industry comprised predominantly of small and medium sized, thinly capitalized firms. Underlying the challenges posed by 
the metal finishing industry is a even more general and fundamental question: Whether the achievement of America's increasingly ambitious and increasingly expensive twenty first century environmental goals means the end of small and medium sized independent domestic manufacturing and its replacement by foreign outsourcing and huge vertically integrated domestic manufacturing.

The Strategic Goals Program (SGP) was a voluntary regulatory program initiated by EPA in 1998 in an attempt to improve the environmental performance of a remaining domestic bastion of small and medium sized firms, metal finishing. Negotiated by EPA, metal finishing trade associations and other stakeholders, the SGP was a direct outgrowth of the Clinton Administration's Common Sense Initiative. Its stated goal was to encourage firms in the metal finishing sector to go "beyond compliance" with existing regulatory requirements. The metal finishing SGP set concrete pollution prevention goals for its participating firms, including a 50 percent reduction in water use, a 90 percent reduction in organics emissions, and a 50 percent reduction in metals emissions, all to be met by a target date of 2002 .

SGP was a voluntary program. By setting broad goals, EPA sought to direct the attention of managers of metal finishing facilities toward finding ways to improve their environmental performance. Facilities that participated received public recognition from EPA and could qualify for various kinds of regulatory relief granted by the publicly owned treatment works (POTW's) who are both the primary recipients and regulators of metal finishers' waterborne wastes. Through these incentives, EPA hoped to encourage metal finishing facilities to improve their environmental management. 
SGP ended in 2003, so now is an ideal time to step back and analyze this

program. I begin this chapter with an overview of the metal finishing industry's structure as well as the federal environmental regulations that apply to the metal finishing industry which are key to understanding the forces behind the SGP. I then describe what is known about the SGP's peformance by examining publicly available federal and state data. I then consider how the SGP's attractiveness and relative success varied by firm type. Finally, I step back and ask whether the metal finishing SGP is something that EPA can or should attempt to replicate in other industry sectors.

My answer to this final question is "no." The metal finishing SGP appears to have disseminated information about pollution prevention and encouraged the most significant metal finishing regulators - local publicly owned water treatment works (POTWs) - to reward with regulatory flexibility those firms that undertake to prevent pollution. Its technical assistance component clearly generated some "win-win" success stories, cases in which relatively and uninformed small metal finishers learned how they could both increase their profits and reduce their pollution by being more efficient in their use of water, metals and other raw material inputs. However, in a highly regulated industry such as metal finishing, where larger firms that have managed to survive have done so only by complying with quite extensive and costly technology-based effluent and emission standards, going beyond compliance is quite costly. The dollar benefits to such firms of marginal regulatory changes (such as reducing self-sampling requirements) are typically small relative to the cost of additional pollution prevention. Managers of middle-tier metal finishing firms who would perhaps have liked to pursue pollution prevention, but faced capital market constraints that prevented them from doing so. The 
SGP did not seem to provide the necessary financial assistance to cover this gap. Finally, the SGP does not appear to have extended regulators' reach to cover the most egregiously non-complying firms in the industry, firms that either escape regulatory detection or are not regulated because they discharge into very small POTW's. ${ }^{1}$

Overall the SGP was neither especially ambitious in its goals nor clearly successful in achieving them. Significantly, SGP failed even to generate the sort of firmspecific database which is necessary to evaluate why firms did or did not participate and whether the initiative caused changes in participants' environmental performance. If EPA wants its experiments in regulatory reform to be more than ad hoc curiosities, it must generate reliable facility-specific quantitative data.

More fundamentally, metal finishing job shops face economic limitations in their ability to make further improvements in their environmental performance. EPA puts metal finishing that takes place within large company manufacturing facilities (so called "captive shops") in a different regulatory category from metal finishing undertaken by independent operators (so called "job shops"). The SGP was intended to help small, capital constrained job shops, not large captive shops owned by capital-rich firms such as General Electric and Boeing. From the point of view of the environment and human health, however, what matters is the industrial process, not where it is taking place. Metal finishing is a process with a very high potential for harmful environmental impact. American society will continue to demand declines in that impact. Yet the experience of

\footnotetext{
${ }^{1}$ It is important to note that under EPA regulations found at 40 C.F.R. $\$ 403.8$, only those POTW's with a total design flow capacity of more than 5 million gallons per day must have an approved pretreatment program for the regulation of discharges into their system by industrial users such as metal finishers. Although EPA estimates that the vast majority of indirect industrial discharges by volume are indeed subject to POTW pretreatment regulation, some environmental groups have argued that in certain states, such as California, most indirect discharges are not in fact regulated or monitored under the Clean Water Act. See Battle \& Lipeles 1998: 372.
} 
the SGP shows that the burden of reducing environmental harm is often too much for small firms to finance. The natural solution, and the one provided by the market, is for such small firms to disappear and for larger manufacturing firms with greater access to capital to assume their operations. To facilitate this economically inevitable and environmentally sound transition, EPA should explore the possibility of coupling tougher emissions standards with a tradeable effluent permit scheme modeled after the one the agency successfully used in eliminating lead additives from gasoline (Nichols 1997). EPA's time and resources would be better spent exploring the feasibility of such a tradeable rights regime for metal finishing and similarly structured industries than in attempting more programs like the SGP.

\section{THE STRUCTURE AND REGULATORY HISTORY OF THE METAL FINISHING INDUSTRY}

The metal finishing industry's structure and regulatory history provide an important backdrop to the SGP. EPA recognized that, while traditional environmental regulation had improved the environmental performance of the metal finishing industry, imposition of further regulatory controls would impose substantial economic hardships upon this already financially stressed industry and cause many small shops to go out of business.

\section{Industry Structure}

According to one EPA source, the metal finishing industry is comprised of more than eight thousand "captive" metal finishers that operate in manufacturing facilities under the umbrella of a larger company and more than three thousand "job shops" that 
operate mostly independently (U.S. EPA 2000, 12379-12380). A typical "job shop" has fifteen to twenty employees and generates $\$ 800,000$ to $\$ 1$ million in annual gross revenues (U.S. EPA 1995a, 5) While employment in job shops has shrunk from a total of 123,300 employees in 1988 to 74,640 in 1997 , the number of job shops increased during the 1990's, from 3294 in 1992 to 3404 in 1997, as did the value of shipments, from $\$ 4.6$ million to $\$ 6$ million (U.S. Census Bureau 1999). As Table 1 below shows, although there has been a slight trend over the 1988-1997 period towards increasing firm size as the number of firms has fallen, close to 90 percent of industry employees work in shops that employ fewer than 50 workers.

\section{Table 1}

Metal Finishing Establishments, Distribution by Size (in percent) (U.S. EPA 1995: 7; U.S. Census of Manufacturers 1997)

\begin{tabular}{|l|c|c|c|}
\hline & $\mathbf{1 9 8 7}$ & $\mathbf{1 9 9 2}$ & $\mathbf{1 9 9 7}$ \\
\hline 1-9 Employees & 47.1 & 48.7 & 48.1 \\
\hline 10-49 Employees & 43.0 & 41.7 & 40.8 \\
\hline 50-99 Employees & 6.9 & 6.8 & 7.8 \\
\hline 100-249 Employees & 2.6 & 2.4 & 2.7 \\
\hline 250 or more Employees & 0.4 & 0.4 & .4 \\
\hline Total & 100.0 & 100.0 & 100 \\
\hline
\end{tabular}

Metal finishing takes place primarily in industrialized states. This locational concentration occurs in part because it is cost-effective for small metal finishing facilities to be near their customers (U.S. EPA 1995a, 7). As of 1997, seventy percent of all metal finishing businesses, accounting for over eighty seven percent of industry shipments, were located in eleven states: California, Connecticut, Illinois, Indiana, Massachusetts, Michigan, New York, Ohio, Pennsylvania, Texas, and Wisconsin (U.S. Census Bureau 
1999). Although all of these heavily industrialized states have large numbers of metal finishing facilities and other metal-related industries (U.S. EPA 1995a), four of them, California, Illinois, Michigan, and Ohio dwarf all others in terms of total metal finishing shipments, contributing almost half of the national total for 1997 (U.S. Census Bureau 1999).

Metal finishers supply to a variety of industries, but the automobile industry is the metal finishing's dominant buyer, accounting for 40 percent of the metal finishing market in 1992, followed by electronics and consumer durables (U.S. Census Bureau 1999). The metal finishing industry is dependent on production by other industries, but sales in the metal finishing industry have not kept pace with sales of the industries it serves (U.S. Census Bureau 1999).

Because metal finishers tend to cluster near their industrial customers, so that competition is localized, the large total number of metal finishing job shops may exaggerate the competitiveness of the industry. Still, based on a recent estimate that, 300 shops comprise about fifteen per cent of the industry, it is clear that metal finishing is far from being an economically concentrated industry. (Nixon 1998: 16).

\section{Environmental By-Products}

Metal finishing is an industrial process that coats an object with layers of metal to control corrosion or friction, improve appearance, or bestow other properties. Metal finishing usually consists of three stages: surface preparation and cleaning, surface treatment, and post-treatment such as rinsing. Wastes generated through these processes include a combination of solvents and cleansers and metal-ion-bearing aqueous solutions 
used for plating. The most common metal-ion-bearing solutions are hexavalent chromium, trivalent chromium, copper, gold, silver, cadmium, zinc and nickel. Acid from the cleaners can be found in the wastewaters, and some of the solvents may be emitted into the air, released in wastewater or disposed of in solid forms (Nixon 1998).

Typical metal finishing wastes include wastewater treatment sludges and spent solutions, base metals, cyanide, solid wastes, and air emissions. Some processes, such as anodizing, produce acid wastes. Other processes produce alkaline wastes. Some processes produce both acid and alkaline wastes (Nixon 1998). In 1993, 2,363 fabricated metal facilities were subject to the U.S. EPA's toxic reporting requirements. These facilities released some 72 million pounds of toxic materials (Nixon 1998).

\section{Federal Environmental Regulation}

The incentive for firms within an industry to participate in a voluntary management-based program such as the SGP depends crucially upon the default or background regulatory environment. It is therefore important to highlight key aspects of the status quo federal regulatory environment against which the SGP was formulated.

Metal finishing generates a variety of wastes and is regulated under a number of media-specific federal environmental statutes, the most significant for metal finishers being the Clean Water Act and the Resource Conservation and Recovery Act. This section highlights the water and waste regulations most crucial to understanding the SGP and shows how metal finishing firms have been affected by these regulations. While the data on the effects of regulation on this industry are not extensive, their message is clear: 
the fear of regulatory enforcement under the status quo regulatory scheme has improved the environmental performance of the metal finishing industry, but the industry is severely limited in its ability to attain further improvements.

\section{Regulation under the Clean Water Act}

Under the federal Clean Water Act (CWA), companies that discharge wastewaters from point sources fall into two general categories: (1) direct dischargers that discharge wastewater directly into streams and lakes, and (2) indirect dischargers that discharge wastewater into municipal sewage systems. The CWA requires direct dischargers to have a permit under the National Pollution Discharge Elimination System (NPDES). These permits specify the maximum quantity of various types of pollutants that may be contained in a discharger's wastewaters. These maximum quantities are derived from technology-based effluent limitation guidelines (ELG's) which means that they represent the amount of various pollutants that may remain in a discharger's wastewater after it has been treated to remove pollutants using a specified wastewater treatment technology.

For most pollutants, ELG's determine what an economist or engineer would naturally call the effluent standard that is included in a particular facility's NPDES permit. Under the CWA, ELG's are categorical, with different industry categories or groups subject to different ELG's. The actual statutory language of the CWA seems to suggest that the severity of the ELG's should vary both with the type of pollutant (e.g., toxic, conventional organic or non-conventional non-toxic pollutants), and also with the vintage of the facility, with new facilities facing tougher "new source performance 
standards" (NSPS). ${ }^{2}$ Federal courts interpreting the CWA have granted EPA vast

discretion in setting ELG's for both existing and new point sources of water pollution.

The legal decisions clearly establish that the agency may consider the economic impact of a proposed ELG only an industry-wide, as opposed to plant-by-plant basis, ${ }^{3}$ but they are equally clear in holding that the agency is under no legal duty to conduct any costbenefit analysis at all in setting ELG's. ${ }^{4}$ In practice, EPA has often set NSPS's at the same level as the "best achievable" or "best conventional" levels mandated for existing sources (Battles \& Lipeles 1998: 172).

This is a quick snapshot of the CWA regulatory scheme for direct dischargers. Indirect dischargers, which discharge wastewaters into municipal sewage systems for treatment by publicly owned water treatment works (POTWs), are regulated somewhat differently. Such indirect dischargers have to comply with both federal and local standards requiring that effluents be reduced from the dischargers waste stream before it enters the POTW. ${ }^{5}$ Like NPDES standards, these are largely technology-based. Unlike the NPDES permit program, which is implemented and enforced either by state or federal regulators (depending upon whether the state has a federally authorized water pollution control

\footnotetext{
${ }^{2}$ For instance, according to the statutory language, existing point sources of conventional pollutants must meet effluent limitations determined by reference to the "best conventional technology," (BCT) where this is to be determined by looking at, among other things, "the reasonableness of the relationship between the costs of attaining a reduction in effluents and the effluent reduction benefits derived, and a comparison of the cost and level of reduction of discharge of such pollutants from the discharge of publicly owned treatment works to the cost and level of reduction of such pollutants from a class or category of industrial sources, and shall take into account the age of equipment and facilities involved, the process employed, the engineering aspects of the application of various types of control techniques..." 33 U.S.C. $\S 1314(b)(4)(B)$. Any point source constructed after the promulgation of such a BCT-based ELG is a new source, and must, according to the statute meet a "standard for the control of the discharge of pollutants which reflects the greatest degree of effluent reduction which the Administrator determines to be achievable through application of the best demonstrated technology." 33 U.S.C. §1316(a)(1).

${ }^{3}$ E.I. du Pont de Nemours v. Train, 430 U.S. 112 (1977).

${ }^{4}$ CPC Intl. Inc. v. Train, 540 F.2d 1329, cert. denied, 430 U.S. 966 (1977).

${ }^{5}$ For a succinct description of the three types of pretreatment requirements, see Battles \& Lipleles 1998: 356.
} 
program), local POTW's have the primary responsibility both to implement and enforce pretreatment standards. (See 40 C.F.R. §403.8). Thus POTW's are both regulated, as direct dischargers, and regulators, of indirect discharges.

Since its passage in 1972, the federal Clean Water Act has succeeded in markedly improving the quality of many of the nation's lakes and rivers. Most of this improvement came about as industrial facilities stopped discharging directly into lakes and rivers and began discharging (as the law allowed them) into municipal sewer systems. The POTWs that process these wastewaters were in turn significantly upgraded due to federal grants and litigation pressure.

Foreseeing an incentive for industrial wastewater dischargers to burden POTWs with their wastewater flows, Congress in the Clean Water Act instructed EPA to set pretreatment standards - the pollution reduction standards that apply to dischargers into sewer systems - at a level equal to the NPDES standards, thereby eliminating the incentive for firms to discharge into municipal systems simply to get the benefit of a more relaxed regulatory regime. Of equal importance, however, federal law allows state and local water regulators to set pretreatment standards that are more demanding than the federal standards. Many of the heavily industrialized states in which the metal finishing industry is concentrated have done precisely that.

Soon after the passage of the CWA, EPA began to write CWA regulations for the metal finishing industry. By 1983, EPA had written two sets of regulations that remain today the most significant CWA regulations for the metal finishing industry. Under these regulations, found in Part 433 of Title 40 of the Code of Federal Regulations, EPA sets out NPDES and pretreatment standards for metal finishing facilities. However, under the 
terms of a 1980 agreement settling a lawsuit brought by the National Association of Metal Finishers (NAMF) and the Institute for Interconnecting and Packaging Electronic Circuits (IIPEC), the regulations provide that job shop electroplaters and independent printed circuit board manufacturers that indirectly discharge their wastes are exempted from Part 433. They are only regulated under rules EPA promulgated in 1979 and located in Part 413 of the Code of Federal Regulations, which set NPDES and pretreatment standards for existing electroplating facilities. EPA agreed to allow the existing Part 413 regulations to remain unchanged for "several years" (U.S. EPA 1980, 45323). ${ }^{6}$ Through the terms of this settlement, EPA indefinitely grandfathered thousands of small, indirectly discharging metal finishing job shops on the grounds that it would be impossible for many of them to remain in business if they had to meet the Part 433 regulations that govern metal finishing more generally.

Not all firms involved in metal processing fell within the regulatory categories covered by Parts 413 and 433. By 1986, EPA had formally identified a "significant number of metals processing facilities" which were discharging a "significant" amount of pollutants, and which were nonetheless not covered by either the metal finishing industry regulations or any other related regulatory provisions (U.S. EPA 1995b: 28,212). By 1992 EPA had created a new, broader industry regulatory category called "Metal Products and Machinery" ("MP\&M") designed to capture many of the facilities that were

\footnotetext{
${ }^{6}$ In justifying the terms of the settlement, EPA explained its reasoning as follows: "EPA is sensitive to the fact that the job shop metal finishing segment is vulnerable to adverse economic impacts as a result of pretreatment regulations. In the preamble to the September 7, 1979, standards, EPA estimated that 587 metal finishing job shops, employing 9,653 workers, may close as a result of these regulations. As to this segment of the metal finishing industry that is economically vulnerable, EPA does not believe that more stringent regulations are now economically achievable. Therefore, EPA does not plan to develop more stringent new pretreatment standards for the job shop metal finishing segment in the next several years. Nor does EPA plan to develop in the next several years more stringent standards for the
} 
currently unregulated. Having created this new category, EPA was statutorily obligated to promulgate effluent and pretreatment standards for it. When the agency proposed rules for the category in 1995, EPA retained the grandfathering of old (pre-1982) indirectly discharging job shops and independent circuit board manufacturers, and also exempted surface finishing job shops; nonetheless, the proposed regulations would have toughed regulatory requirements for a considerable number of metal finishers (U.S. EPA 1995b: 28,215).

In 2001, EPA revised the new MP\&M regulations to replace the existing regulatory scheme for metal finishers, including electroplaters. The metal finishing industry viewed these proposed MP\&M regulations for direct and indirect dischargers as a major threat. Not all metal finishers would have been equally affected by the new regulations. Indeed, EPA found that while the technological wastewater treatment method it used to establish the new "best practicable technology" (BPT) and BCT effluent guidelines and pretreatment standards was already in use by all of the fifteen directly discharging metal finishing job shops, only 55 percent of the 1500 indirectly discharging metal finishing job shops were using it (U.S. EPA 2001a). Still, as of 2001, EPA estimated that the costs imposed by the new proposed wastewater treatment technologies would result in the closure of only 10 percent of the indirect discharging metal finishing job shops (U.S. EPA 2001a).

By the summer of 2002, EPA was in the midst of a major reconsideration of the proposed MP\&M rules (U.S. EPA 2002). In May, 2003, EPA withdrew the proposed new regulations of the metal finishing industry in their entirety (U.S. EPA 2003). What 
had happened to cause this dramatic reversal? Although the timing of the withdrawal soon after Bush replaced Clinton in the White House -- might suggest that political pressure was exerted within EPA, I have found no evidence to support such a suggestion. Instead, it seems that this is a case where the notice and comment rulemaking process worked as it is supposed to, giving the regulated sector a chance to amass data to persuade the agency to change course. The metal finishing trade association spent over $\$ 1$ million preparing detailed economic and engineering studies showing that because most metal finishing job shops are engaged in a variety of different finishing operations, using a variety of different metals, it would cost them far more than EPA had assumed to meet the proposed new standard. On the benefits side, trade association consultants discovered a number of errors in EPA's estimation of the amount of wastes such as cyanide currently found in typical metal finishing wastewaters. These errors tended to vastly overstate both the amount of waste currently being generated and the environmental benefits of the proposed new treatment requirements.

EPA's withdrawal of the rulemaking acknowledged that the agency had been wrong. The document explained the decision not to promulgate new metal finishing regulations on the grounds that new data submitted in comments by the industry had caused it to: (1) drastically revise upward its estimate of the number of directly discharging job shops that would close from 0 to 12 (50 percent of the reported 24 existing direct dischargers, a number that had EPA had incorrectly taken to be only 15); (2) doubt the effectiveness of the proposed technology in removing metal wastes from waste streams containing a wide variety of metals; and (3) increase the number of indirectly discharging job shops that would close as a result of the regulation from 10 to 
46 percent of such facilities (U.S. EPA 2003: 25,704-25,705). In rejecting mandatory environmental management systems and other pollution prevention alternatives, EPA noted significantly that "many metal finishing job shops are currently employing best management/pollution prevention practices similar to those described in the proposal as part of the National Metal Finishing Strategic Goals Program" (U.S. EPA 2003: 25,692). EPA's management-based voluntary program had effectively substituted for mandatory wastewater treatment technologies.

\section{Regulation Under RCRA}

The Resource Conservation and Recovery Act (RCRA) was passed in 1976 with the purpose of reducing the generation of hazardous wastes and improving how waste is handled and disposed. RCRA sets standards to govern the generation, treatment, storage, transportation, and disposal of hazardous wastes (Jalley et al. 2002).

RCRA and its legislative amendments have set up a "cradle to grave" system to regulate hazardous wastes. This monitoring system consists of six elements: (1) identification and listing of hazardous waste, (2) a manifest system to trace the life cycle of the waste from generation to disposal, (3) minimum standards for waste treatment, (4) storage and disposal requirements, (5) requirements for state implementation of hazardous waste management, and (6) an enforcement program.

The consensus view about RCRA among both academic commentators and practitioners is that while it surely has made industries much more careful in their 
handling, storing and disposing of hazardous waste, ${ }^{7}$ the RCRA regulatory system is a "horrible" (Stoll, 2003: 6) maze of "mind-numbing," complex, technology-based rules (American Mining Congress v. EPA: 1189). For the metal finishing industry, a longstanding complaint about RCRA was EPA's rule that generators of greater than 1,000 kilograms of hazardous waste per month may not accumulate hazardous waste on site for longer than 90 days without obtaining a RCRA permit (40 CFR 262.34). The problem for generators was a simple issue of transportation costs. The roughly 1300 metal finishers producing hazardous wastewater sludge in amounts that exceed the regulatory requirements for small quantity generators did not generally create enough of such wastes within 90 days to fill a full truckload. To get the waste off-site without being deemed waste storage sites under RCRA, these metal finishers were shipping many partial loads. Because there is a fixed cost just to bring a truck to and from a facility, metal finishers could significantly lower their waste disposal transportation costs if they were allowed to retain waste on-site for a longer period.

In 2000, EPA revised the rule in question to allow waste generators to retain socalled F006 waste, the hazardous wastes from wastewater sludge, on-site for up to 180 days, provided that they recycle the waste, implement pollution prevention practices to reduce the toxicity of the sludge or make it more amenable to metal recovery, have no more than $20,000 \mathrm{kgs}$ of the waste on site at any time, and comply with RCRA requirements on storage, labeling, personnel training, waste analysis, and record keeping (40 CFR 262.34(g)).

\footnotetext{
${ }^{7}$ In the case of metal finishing, Duke (1994: 59) concludes his study of metal finishers' waste minimization practices by remarking that "economic incentives to avoid costly and burdensome RCRA regulations do
} 


\section{Effects of Regulation on Metal Finishers' Environmental Performance}

Since the finalization of key federal regulations in the mid-1980's, the metal finishing industry's environmental performance has improved markedly. Normalized by annual value of shipments, toxic releases from firms with emissions large enough to be reported on the federal Toxic Release Inventory (TRI) declined by 44\% between 1993 and 2001. (U.S. EPA 2004: 33). The number of civil and criminal enforcement actions against firms within the industry has likewise fallen.

Federal environmental regulation seems to have led to two types of effects that are responsible for this improvement in metal finishing industry environmental performance. The first and most direct effect was to cause the closure of many of the most marginal, worst-polluting firms that simply could not comply with federal environmental requirements. Until the 1980 's, the metal finishing industry was an environmental disaster area, with typical facilities dumping and draining their wastes without treatment, and with wastes accumulating all over facility sites. ${ }^{8}$ Many of the environmentally dirtiest firms were also economically marginal, and they closed as soon as environmental regulation became a reality.

These firms left a legacy of contaminated real estate that regulators are still dealing with today. The metal finishing industry did not, however, disappear, and the second effect of federal regulation was to improve the environmental performance of surviving firms. Indeed, all of the metal finishers who participated in a recent interview study conducted by Gunningham, Thornton, and Kagan (2004) opined that their

encourage hazardous waste generators to minimize their waste streams."

${ }^{8}$ As one shop owner put it, "17 years ago...we were accumulating waste under the decks and there was two feet of sludge under the floor from drips and spillage." Another commented: "if you had to get rid of something you just dumped it" (Gunningham, et al. 2004: 7). 
industry's improved environmental performance was due mainly to regulatory enforcement. (See also Duke 1994). Indeed, almost half of their respondents said that the reason they had undertaken a specific environmental improvement was because a fine or imprisonment had occurred at their firm or at another metal finishing firm (Gunningham, et al. 2004). Reflecting the industry's relatively abysmal pre-regulatory environmental performance, the available evidence indicates that much of the improvement in metal finishers' environmental performance has been achieved through very simple housekeeping improvements, such as exercising more care in handling or cleanup, and basic treatment techniques, such as dewatering waste sludges. (Duke 1994: $54-58)^{9}$

The common complaint by environmentalists that the fines for environmental regulatory violations are too low to make a difference seems not to apply to the smalland medium-sized firms that make up the metal finishing industry. A substantial number of metal finishing firms say that they personally know about instances where metal finishing firms have shut down because they were unable to pay the fines for environmental violations. Indeed, the metal finishing industry was the only industry of six studied by Gunningham, et al. (2004) in which every respondent thought that fines could cause firms to shut down. Given that fines do have bite in this sector, metal finishers tended to view the choice between regulatory compliance and non-compliance

\footnotetext{
${ }^{9}$ On the other hand, Duke et. al. (1998: 36) found that over the period 1993-1995, stormwater pollution loads increased in a sample of 130 Los Angeles metal finishers and fabricators. The stormwater regulatory regime, however, is far different in several respects from the regimes governing air and water pollution; moreover, Duke et. al. did not attempt to control for a number of potentially confounding factors.
} 
as one of whether to stay in or go out of business. For metal finishers, environmental

compliance is a concern second in importance only to the general state of the economy. ${ }^{10}$

\section{THE METAL FINISHING STRATEGIC GOALS PROGRAM}

The Strategic Goals Program grew out of EPA efforts to "reinvent" its regulatory programs to improve their efficiency and effectiveness. Data on the effectiveness SGP as an alternative or supplement to traditional regulation are limited, but they do indicate that far fewer firms participated in the program than EPA had sought. This result is perhaps not surprising given the economic incentives facing the metal finishing industry and its structure.

\section{Origin and Elements of the SGP}

The Metal Finishing Strategic Goals Program (SGP) was a direct result of EPA's Common Sense Initiative (CSI), one of the early regulatory reinvention efforts launched by EPA in 1994 during the Clinton Administration (Coglianese and Allen 2004). The CSI metal finishing industry subcommittee was composed of representatives from industry, environmental groups, labor organizations, and state, federal and local regulators. This subcommittee developed the seven goals that became institutionalized in the Strategic Goals Program, which EPA created in 1998. Six of the goals were in the form of quantitative reductions relative to 1992 baseline levels:

\footnotetext{
${ }^{10}$ See Finisher's Management, State of the Industry: 2001 Survey on Environmental Compliance, available at http://www.finishers-management.com/novdec2001/sofi2002.htm (last visited December 1, 2003).
} 
- 50 percent reduction in water usage

- 25 percent reduction in energy consumption

- 50 percent reduction in land disposal of hazardous sludges and an overall reduction in sludge generation

- 50 percent reduction in metals emissions to water and are

- 98 percent reduction in metals use

- 90 percent reduction in emissions of organic toxics reported under the Toxic Release Inventory

The seventh, non-quantitative goal called for a reduction in human exposure to toxics both in the facility and in the surrounding community. ${ }^{11}$ According to industry sources, the reason that the SGP backdated its baseline to 1992 (rather than using 1998, the actual year of program inception) was to avoid in effect punishing metal finishers who had already achieved significant reductions in waste generation and resource use before the program began. At the same time, while the subcommittee called upon the industry to achieve the SGP goals within ten years, progress was to be assessed in 2002, so that the ten-year timeframe was really a four-year period.

The subcommittee also recommended the amendment to the section of RCRA governing on-site storage of wastewater sludge and undertook a project to determine whether metal finishing wastes had become less toxic since the rule was proposed two decades earlier. Phase I of this latter project was completed in 1998 and published as the Metal Finishing F006 Benchmark Study (U.S. EPA 1998). Phase II involved an effort to develop regulatory and administrative strategies to "promote metal recovery of F006

\footnotetext{
${ }^{11}$ For a statement of these goals, see http://www.strategicgoals.org/coregoals.cfm (last visited February 1, 2005).
} 
waste, encourage pollution prevention practices related to the generation of F006 waste, and reduce or remove possible RCRA barriers to metals recovery of F006 waste" (U.S. EPA 2000, 12380). The subcommittee also identified a new chromium filtering approach that is expected to reduce chromium air emissions and cut costs by 90 percent.

The SGP's plan for accomplishing its goals consisted of two components. The first was to communicate information regarding best practices in metal finishing source reduction and pollution prevention to as wide an audience within the industry as possible. As part of this strategy, EPA and the metal finishing industry would work together to improve recordkeeping and tracking among industry members and recognize firms that participated in these efforts (U.S. EPA 1999). The second component of the SGP was to create a financial incentive for companies to adopt best practices voluntarily. EPA pledged to encourage POTWs that implement and enforce CWA regulations to develop a tiered approach to regulating metal finishers. POTWs would relax regulatory requirements on metal finishing firms that had met or were on the way to meeting SGP goals. The regulations targeted for relaxation were rules that were particularly costly to comply with but not socially productive for firms attempting to go beyond compliance.

Two years into the program EPA reported that SGP had made an "impressive start,"with 425 metal finishing firms, 21 states, and 80 local POTWs in the program (U.S. EPA 2001b, 5). EPA touted the "tremendous progress"(U.S.EPA 2001b, 6) made by industry participants in meeting the various performance goals, with the average SGP metal finisher reducing water use by 41 percent, energy use by 14 percent, hazardous sludge sent for landfill disposal by 36 percent, air and water releases of TRI metals and cyanide by 58 percent, and organic TRI releases by 77 percent. (U.S. EPA 2001b). The 
original goal of a 98 percent reduction the use of metals - which, given the fact that metals are the primary input to metal finishing, would seem impossible to achieve without substantial decreases in firms' production levels - was modified by the SGP Steering Committee to mean either a 50 percent reduction in wastewater treatment sludge, or land disposal of just two percent or less of the metals used by a facility (U.S. EPA 2001b, 11). According to EPA, 112 SGP facilities met this goal by the program's midway point, primarily by recycling their sludge (U.S. EPA 2001b, 11).

EPA's 2001 report contained several examples of how firms in the SGP achieved such large reductions in water use and waste generation (U.S. EPA 2001b, 8-12). A firm in Ohio, for instance, was able to reduce its water usage simply by capturing all wastewater in a batch tank rather than discharging directly into the city of Cincinnati's sewers. A Colorado- and Nebraska-based nickel chrome finisher providing parts for Harley-Davidson motorcycles changed its production process by improving its monitoring of the tanks in which parts are bathed so as to prolong the life of the bath, thus reducing the amount of waste sludge created. A Portland, Oregon firm dramatically reduced its water usage by installing two cooling towers. Other stories involved companies that had reduced the amount of wastewater sludge sent to landfills by drying the sludge and sending the dried sludge to metal recycling facilities.

\section{Perspectives on the SGP's Performance}

Although EPA's 2001 report on the midterm progress of the SGP touted the program's success, a closer look in light of more recent data reveals a more complex 
story. Data current to 2003 show, for example, that while the goal of a 50 per cent reduction in metals emissions to air and water was exceeded (with a 57.8 per cent reduction by 2002); the program fell short of its goal of a 50 per cent reduction in sludge generation and land disposal of sludges, however, with sludges reduced by only 3 per cent and land disposal of sludges by 15 per cent. ${ }^{12}$ The program's participation rate, however, was far short of its goal of roughly 1,050 (80 percent of a conservatively estimated total number of 1,300). ${ }^{13}$ Indeed, although EPA's "Living the Vision” 2001 progress report on the SGP claimed that 425 metal finishers were participating in the program (EPA 2001b, 5), its national dataset shows that the number of metal finishers who were actively and fully participating in the program - by turning in annual reports -reached a peak of 226 in 2000, with only about 113 still reporting at its conclusion in 2002. ${ }^{14}$ Given the likelihood that the most committed, best performing firms were the ones that took the time to fill out annual reports, EPA's data likely overstate the program's achievements.

In order to fully evaluate both the SGP's relative success in stimulating waste reduction and its apparent failure in getting high participation, one needs two things: more detail on the numbers, and benchmarks for comparison. An initial problem with the waste reduction numbers is that EPA never verified them. According to the industry's

\footnotetext{
${ }^{12}$ All these goals are in terms of sales normalized figures. The most recent data on metals discharged to air and water, sludge generation and sludge disposal are available at http://www.strategicgoals.org/reports2/t9.cfm?state=all\&requesttimeout=300; http://www.strategicgoals.org/reports2/t5.cfm?state=all\&timeout $=300$; http://www.strategicgoals.org/reports2/t6.cfm?state=all\&timeout=300 (last visited February 2, 2005).

${ }^{13}$ The number of 1300 metal finishing job shops is taken from EPA's May 13, 2002 Rulemaking announcing its decision not to revised CWA standards for the metal finishing job shop industry (U.S. EPA 2003). This number differs from the number of facilities included in the 3471 SIC category that is reported in the Census of Manufacturers, because the census number includes captive shops (U.S. Census Bureau 1999).
} 
trade association, the methodology for generating and checking the numbers was produced by an outside consultant. Given that participation in the SGP was voluntary, reliance upon an outside contractor is perhaps the best that could be hoped for, and not materially different from what EPA would have done on its own.

A bigger problem for ex post assessment of the SGP is its failure to generate firmspecific data. Ideally, one would have detailed firm-level data not only on the level of wastes generated both before and after the initiation of the program, but also on other firm attributes that theory suggests should be relevant to a firm's decision whether to participate. Similarly, detailed firm-specific data on firms that did not participate in the SGP would then permit econometric testing of various theoretical hypotheses about why firms participated as well as of the question of whether participation had a statistically significant effect on waste reduction performance over the relevant time period.

The primary reason why the SGP did not generate such firm-specific data is that firms agreed to participate only on the condition that such firm-specific data not be made publicly available. One can understand why metal finishers would have preferred such non-disclosure - environmental groups and others who had never "signed on" to the SGP could use SGP reports in citizen suit litigation. But EPA's decision to agree to such nondisclosure is questionable. Completely aside from legal issues (can, for example, EPA evade Freedom of Information Act disclosure obligations by putting data collection and dissemination in the hands of a separate entity such as SGP?), the agency cannot learn whether voluntary programs such as SGP work or not unless such programs generate

\footnotetext{
${ }^{14}$ The number of participants is constant for all reports except energy use, where even fewer firms reported. For the representative numbers, see, for example, the water discharge trend report, available at http://www.strategicgoals.org/reports2/t4.cfm?state=all\&timeout=300).
} 
firm-specific data. Moreover, it may be possible to provide such information without revealing firm identity simply by assigning each firm a coded identity.

In the absence of firm-specific data from the SGP itself, one is left to draw what inferences one can from the data that SGP did provide, and from data about metal finishing environmental performance generated independently of the SGP. In evaluating the program's aggregate performance, a useful benchmark is provided by a study done in 2000 by the National Center for Manufacturing Sciences (NCMS 2000). That study produced metal waste reduction goals for zinc, decorative chromium, electroless nickel and hard chromium plating. These goals were set equal to the performance of the topperforming quartile of metal finishing firms in a sample of such firms conducted by NCMS. Under that methodology, the NCMS study recommended sector-wide reduction goals of 54 percent for zinc wastes, 73 percent for nickel wastes, and 71 percent for chromium wastes. Recall that the SGP set a goal of 50 percent reduction in metal wastes and reduction of simply any magnitude in sludge. The SGP's data claim a 16 percent reduction in sludge and 37 percent decrease in wastewater. While the sludge reduction meets the SGP goal - which was any reduction at all - the wastewater reduction falls below the SGP goal. More importantly, the SGP's goals were much more modest than the waste reduction objectives recommended by the NCMS study - 50 percent versus an NCMS average of 65 percent. Compared to the NCMS objectives, the SGP appears to have failed to set its sights high enough in the first place, and then to have fallen short of what the NCMS viewed as achievable by the typical firm within the industry.

The only firm-specific data I have found comes from a pollution prevention report issued by the state of Minnesota's Office of Environmental Assistance in 1999 (MOEA 
1999). This report presents Toxic Release Inventory (TRI) data for the twenty-six

Minnesota metal finishing firms (both captive and job shop) that reported TRI data in 1999. Six of these firms participated in the SGP. I compared the environmental releases of SGP and non-SGP firms included in this study. The sample is small, and I did not identify which firms on the Minnesota list were captives and which were job shops. With these caveats, Figure 1 compares the average change in TRI emissions between 1995 and 1999 for SGP and non-SGP metal finishers in Minnesota.

Figure 1

Minnesota Metal Finishers

1995 - 1999 Change in Selected TRI Emissions

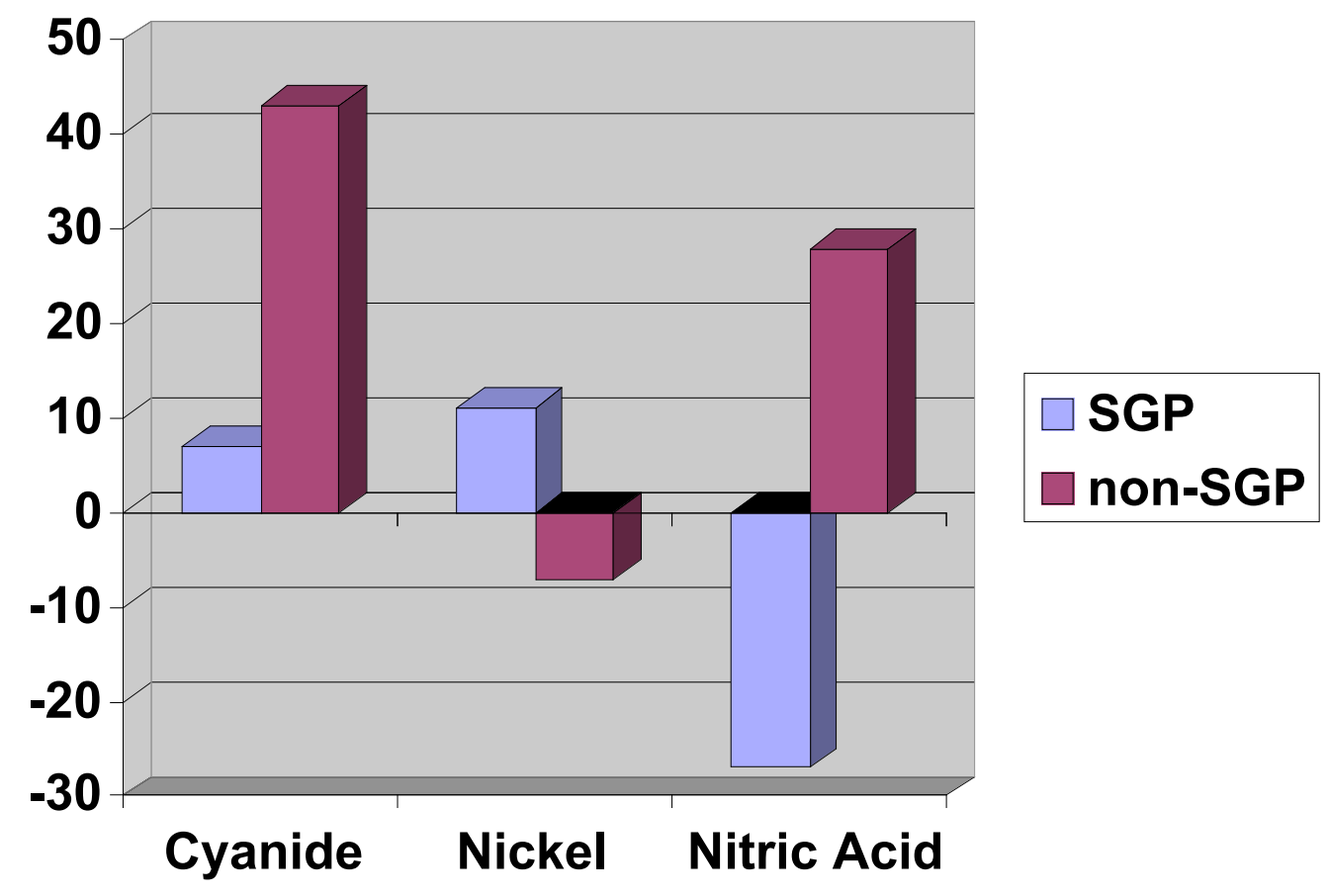


The data reported in Figure 1 suggests that for cyanide and nitric acid emissions, Minnesota SGP participants were doing better than non-SGP metal finishers, while they had a worse record in reducing nickel reductions. This conclusion depends, however, upon the exclusion from the sample of one SGP firm which increased its cyanide emissions by 1220 percent over the period. If that firm is included, then SGP firms in Minnesota did better than non-SGP firms only for nitric acid.

It may be argued that Figure 1 is not relevant to evaluating the SGP, because it does not cover the entire period of the program. However, the SGP's own reported aggregate data raise questions about whether the SGP actually helped firms improve their performance, or whether the program simply attracted firms that were already good performers. As observed by Coglianese and Allen (2004), these data show that most SGP firms made little progress in achieving program goals after SGP was launched in 1998, with much of the progress that did result occurring before the program even began. For instance, normalized (by sales) hazardous waste sludge generation by SGP firms went down by 16 percent in the first two years of the program, but in the program's third year went back up to its initial level (Strategic Goals Program 2001b). Similarly normalized toxic organic chemical emissions went down until 2000, but then increased by 30 percent (Strategic Goals Program 2001c). Only water discharge, which went down 37 percent relative to 1992 baseline usage, fell continuously during the entire life of the SGP period (Strategic Goals Program 2001d). Whether this one unambiguous change resulted from the program, however, is unclear: by 1996, over ninety percent of metal finishing shops 
had already introduced measures to reduce drag-out and rinse water volumes (Washington State Department of Ecology 1996). ${ }^{15}$

As to the question of why some firms joined and some did not, there is once again a dearth of systematic evidence. While many firms in Indiana and Michigan participated, few firms in other states with large metal finishing industries chose to take part. Of the 23 metal finishing job shops in the state of Washington as of 1999, only two were SGP participants. In California, the state with the largest metal finishing industry, only twelve shops participated in SGP. Most of the sixteen biggest generators of hexavalent chromium and cyanide wastes in the California metal finishing sector are captive metal finishers (e.g. Boeing Satellite Center), but several are independent job shops, and none participated in the SGP (CA DTSC No date). At the conclusion of a multi-media enforcement effort in 2000, the "general perception" of California environmental regulators was that the chromium plating industry in that state "ha[d] compliance problems in all environmental media" (CA DTSC No date, 5). The general pattern seems to be one in which participation in the SGP clustered in certain states and localities.

\section{Explaining the SGP: An Economic Approach}

The field of economics offers explanations as to why individual firms and their trade associations might participate in voluntary management-based strategies such as the metal finishing SPG. In this section, I review these explanations and explore the extent to which an economically motivated account can explain some of the general features of this program.

${ }^{15}$ Dragout refers to the contamination of rinse water by plating process solutions that drip from parts being 
Economic Incentives for Management-Based Voluntary Programs

The SGP was one of many so-called voluntary environmental programs initiated during the Clinton Administration. As described above, it emerged from that Administration's Common Sense Initiative (CSI). Like other voluntary programs of that time period, such as EPA's Project XL, the SGP involved a commitment by participating metal finishing firms to improve their environmental performance beyond what was legally required. ${ }^{16}$ Unlike Project XL, however, which involved negotiated agreements between federal, state, and local regulators and individual facilities, the SGP was a sectoral initiative. Explaining the SGP requires understanding both the general incentives for individual firms to go beyond existing regulatory requirements as well as the particular incentive issues raised by attempts to improve the environmental performance of an entire industry sector.

Firms may undertake any number of costly activities, for any number of reasons. If a firm has substantial market power in one or more industries and is generally well-run, it will typically have plenty of free cash flow. This cash flow gives the senior management of such companies discretion over company policy, particularly closely held firms that are not subject to the discipline imposed by public stock markets. For publicly traded firms, the stock market may eventually discipline policies that harm the bottom line by lowering a company's stock price, but the stock market's ability to discipline

plated. Reducing dragout reduces the amount of chemicals and water used in the production process. ${ }^{16} \mathrm{I}$ have taken this very useful general definition of a voluntary approach from Carlo Carraro and Francois Leveque (1999). In the taxonomy provided by Thomas P. Lyon and John W. Maxwell (2004: 4-5), the SGP would be classified as a public voluntary agreement. 
inefficient management is contingent upon a number of variables, including most importantly the complexity of firm financial structure and transparency of firm financial performance. Given the substantial discretion that senior corporate managers enjoy over policy choice and their hierarchical control position in their organizations, a firm may voluntarily improve its environmental performance simply because its current CEO has decided to make the environment a priority regardless of how such a priority affects the firm's bottom line profitability (Kagan et al. 2003).

The existing economic literature on voluntary environmental programs has devoted relatively little attention to managers' altruistic motives for participation in such programs. The literature has instead discussed a variety of self-interested reasons why individual firms might participate in voluntary environmental programs. There is, on the one hand, the green gold hypothesis associated with Michael Porter (Porter 1991; Porter \& van der Linde 1995), which holds that by trying to improve their environmental performance firms often discover previously unknown ways of lowering their costs and increasing their productivity. While case studies suggest that such opportunities have sometimes been realized, economists by and large remain skeptical that merely by trying to improve their environmental performance, firms can discover opportunities to lower costs (Boyd 1998; Palmer, Oates \& Portney 1995).

By contrast, economists have shown that the presence of consumers and investors who care about firm-specific environmental performance, and will pay a premium price for the products or stock of firms with superior environmental performance, may create a direct profit motive for a firm to establish a reputation as a strong environmental performer (for a rigorous demonstration of conditions under which this motive exists, see 
Small \& Zivin 2002). However socially responsible consumers and investors may not create an incentive for actual investment in improved environmental performance, but only in investments in public relations to create a widespread perception of such improved performance that may belie a quite different reality (Johnston 2004).

Regardless of the reality behind such perceptions, there is one important type of customer demand for such improvements: large firms that buy parts, products, and materials from smaller suppliers. Originating in the goal of quality control, so-called "supply chain management" has become a tool by which large firms attempt to improve the environmental performance of their typically smaller suppliers. There are a number of reasons why such big firms might want to push their suppliers to improve their environmental performance, ranging from concern that laws someday may change to hold them liable for the environmental harms caused by their suppliers (a specter made quite thinkable by the Superfund law's regime of strict, retroactive, and joint and several liability for hazardous waste cleanup), to more immediate concern about their own image with consumers and investors. Whatever the reason, if big customers demand environmental performance as a condition for continuing to buy, small suppliers with serious competitors have an obvious incentive to accede to such demands.

A third economic account of why firms participate in voluntary environmental programs is that they view such programs as a strategic tool, to be used like more traditional lobbying and litigation to persuade politicians and regulators to relax or at least not toughen the firm's environmental regulatory compliance requirements. On this explanation, participation in voluntary environmental programs is a form of strategic regulatory preemption (Maxwell et al. 2000; Segerson and Miceli 1998). The difficulties 
regulatory beneficiaries face in securing new, tougher regulatory standards means that firms may readily stave off new regulation by voluntary committing to levels of performance that are higher than those currently required but lower than those that regulatory beneficiaries prefer.

All three economic explanations help to illuminate the behavior of a manager of an individual firm faced with deciding whether to join a voluntary environmental program. However, two of these economic explanations are not likely to operate at the level of an industry sector such as metal finishing. In environmental regulation, industry sectors are collections of firms that may or may not be direct product market competitors, but use sufficiently similar production processes so they have to comply with the same set of technology-based regulatory standards. Industry sectors take action through their trade associations (Johnston 2004). If firms are competing against one another, they have an incentive to find new and better ways to lower costs or increase revenues, and they will treat those ways as proprietary information not to be shared with competitors. A firm will not want an industry trade association to share with its competitors information about cost savings it yields through pollution prevention or any revenue increases it reaps due to attracting green consumers. In other words, while green gold and green consumers and investors may motivate individual firms to participate in voluntary environmental programs, these reasons are unlikely to account for industry trade association involvement in or sponsorship of such programs.

This is not true of strategic regulatory preemption. Under the existing regulatory regime, firms within a given regulatory sector face the same technology-based regulatory standards. Proposals to toughen regulations threaten all firms within a sector with a 
regulatory cost increase. All firms within the affected sector share a common interest in contributing to a voluntary environmental program that might preempt such costly proposals from being finalized.

These basic theoretical predictions about individual firms and their trade associations follow only under the assumption that the sector consists of identical firms that are product market competitors. Under a different set of assumptions, dominant firms within trade associations may have an incentive to use the association to publicize the cost-saving and revenue-enhancing advantages of improved environmental performance among association members. Most simply, if firms within the association are not direct product market competitors, but simply fall into the same regulatory category, then they will suffer no competitive loss by sharing information about how to achieve better environmental performance. Even if firms do compete in product markets, larger firms within a trade association that tend to have high public and regulatory visibility may have a distinct incentive to use the trade association to promote compliance with voluntary environmental programs by smaller firms within the industry. As observed by King and Lenox (2000), a large firm such as DuPont may bear a disproportionate share of the collective reputation of firms within the chemical industry, and for this reason may have an incentive to take steps through the industry trade association to improve industry-wide environmental performance.

Trade association activity may also be both motivated and justified by the public good aspect of investments in pollution prevention. By patenting its invention, a firm that discovers a new pollution abatement technology can capture close to the full value of its invention by selling it to other firms that wish to adopt it. Of course, new production 
methods or management practices that prevent pollution or reduce raw materials usage are generally difficult to patent. A firm that discovers such new methods may have difficulty preventing other firms from simply copying what it is doing. If pollution prevention exhibits the characteristic of non-excludability, then pollution prevention innovators will have an inadequate incentive to innovate. Non-excludability might also imply that there is little a trade association can do to overcome this underinvestment problem.

This conclusion neglects the information role played by such associations. While some trade association members may find out quickly on their own about new ways to prevent pollution and cut materials usage, others may never get such information unless their trade association provides it to them. For many members, investments in an effective trade association are a way to get information that can directly improve their economic performance. The financial contributions of its members may thus allow a trade association to subsidize the creation and dissemination of information about new pollution prevention methods. While the evidence is at best mixed on whether voluntary environmental programs initiated by trade associations lead to real improvements in the environmental performance of participating firms (Howard et al. 2000), there are instances in which trade associations have acted to publicize and promote the adoption of improved environmental practices within their industry, even if these might improve the competitive position of some members (Schwartz et al. 1999). 
Applying the Economic Account to Explain the Metal Finishing SGP

Although I have been unable to discover any systematic study of the economic structure of the metal finishing industry, anecdotal data suggest that due to the relatively high cost of transporting metal products to and from finishing shops, such shops will be located close to their customers, so that competition within the industry may be expected to be highly localized. Anecdotal data also suggest that the metal finishing industry may consist of two quite different types of firms: a lower tier of firms that provide a relatively low-quality, low-price product and which have little competitive slack, and an upper tier that charges premium prices for high quality products.

There has, by contrast, been more systematic study of what may be called the regulatory structure of the metal finishing industry. By regulatory structure, I mean the way in which metal finishing firms differ in their attitude toward and history of environmental regulatory compliance. The metal finishing industry was one of the first industries studied as part of EPA's "Sector Strategies" initiative, and the agency's report on metal finishing portrays distinct tiers of firms within the industry (EPA 1994: 25-28). These tiers bear a striking resemblance to those Kagan reports in his study of pulp and paper mills in Chapter 2 (Kagan 2005). At the highest tier are firms that have been regulated and expect to continue to be regulated in the future, and that also expect a long future in business. While managers of these firms may differ in how they express their environmental attitudes - some say they care about their environmental performance simply because it is the "right thing" to do, while others express more self-interested 
motives - they all share a strong interest in the maintenance of a cooperative, long-term relationship with regulatory authorities. Because they anticipate a continuing regulatory relationship, such firms are willing to go beyond what regulators may currently require.

At the next tier are firms that will comply with regulations only out of fear of enforcement, and whose ability to comply (let alone go beyond compliance) may be severely limited due to their relatively precarious financial state. When it comes to the sorts of small and medium sized enterprises (SMEs) that make up the metal finishing industry, these firms - what Kagan calls the "reluctant compliers" - are more the rule than the exception.

The final and lowest tier of firms is made up of those firms that simply do not comply with environmental regulations. That they get away with non-compliance is due either to the fact that regulators with limited budgets simply cannot inspect and enforce against every firm out of compliance, or because the firm actively takes steps to avoid detection by regulators. For these "non-compliers," the avoidance of regulatory compliance costs may be a key aspect of an overall competitive strategy to undercut competitors' prices.

There is a parallel between my conjectures regarding the economic structure of the metal finishing industry and the evidence on the existence of tiers in the industry's regulatory structure. This parallel generates the following predictions about the metal finishing SGP:

- Metal finishing markets are both local and specialized. The composition of firms within any given local market is therefore likely to vary with the nature of the customer base in that market. Within any geographic market, the 
greater the environmental sensitivity of a metal finisher's customers, the stronger the incentive for a finisher to participate in the SGP. In some markets, certain job shops may do such a high percentage of their work for one or two large customers that they are de facto captive, and for such shops, supply chain pressures may strongly influence their incentives for environmental performance;

- While customer-driven, supply chain incentives for participation are likely to vary with location and a particular shop's customer base, both the green gold and strategic regulatory preemption incentive for participation are likely to be relatively constant across geographic areas.

- Within any given metal finishing market, the long-term, relatively highquality firms, that are also top tier regulatory performers, would be most likely to participate in the SGP. Not only would such a program provide them with a relatively low-cost way to signal their environmental commitment to local POTWs, but it would also provide them an opportunity to participate in strategic regulatory preemption with respect to federal environmental regulators. Moreover, because such firms have shouldered the burden of federal and local regulators' perceptions about the poor environmental performance of metal finishing industry, they would have had an incentive to support any program, such as SGP, that promised to improve the performance of lower-tier firms.

- The next tier of firms - those with lower quality but also lower price - face great economic uncertainty and therefore have a relatively short horizon in 
thinking about investing in potentially costly voluntary programs such as SGP. Such firms would generally be expected to free ride on the lobbying efforts of the industry trade associations. The SGP held out the potential to benefit firms by persuading local POTWs to adopt a more flexible regulatory approach. It also offered financial and technical assistance in pollution prevention. Indeed, the dominant reason for such firms to participate would likely have been the SGP's potential to provide green gold in the form of information about money saving pollution prevention techniques.

- For the bottom tier of non-complying firms, the SGP would have been irrelevant. Since the strategy of such firms is to evade regulation, participation in a voluntary regulatory program would be nonsensical.

Although data limitations make it impossible to test these conjectures systematically, it is possible to test them indirectly by comparing them to the stylized account of the metal finishing industry's response to, and shaping of, the SGP. The regulatory regime against which metal finishers ought rationally to have evaluated participation in the SGP was one of extremely high regulatory visibility and the specter of even greater regulatory stringency as EPA moved toward implementation of effluent and pretreatment Clean Water Act regulations for captive and job shop finishers. The simplest case in which profit-maximizing firms will agree "voluntarily" to go beyond existing environmental regulatory requirements is when new regulations would soon force them to improve anyway. In this case, "voluntary" improvement does not involve any marginal cost relative to what regulations would soon require, but brings the marginal public relations benefit of allowing the firm to tout its record in going "beyond 
what the law requires." Given that EPA had in fact proposed new, tougher regulations in 1995 , it is likely that some metal finishers would have agreed to participate in the SGP simply to receive good publicity from doing what they expected regulations would soon require them to do.

The regulatory history discussed above suggests that strategic regulatory preemption was a significant motive behind the SGP, both from a sectoral point of view and from the point of view of particular, larger firms in the industry. Throughout EPA's consideration of whether to promulgate new effluent and pretreatment standards for metal finishers, the industry trade association and individual firms argued repeatedly that the industry should be given a chance to show that it would voluntarily improve its environmental performance through the source reduction and pollution prevention steps promoted by the SGP, and that new regulations were simply not needed. EPA's May, 2003 decision not to revise effluent and pretreatment standards for metal finishing industry explicitly noted the improvements the industry was making on its own under the SGP. Finally, while it may be coincidental, the SGP was terminated at precisely the time when EPA decided not to promulgate the new, tougher effluent and pretreatment standards.

That self-interest in forestalling regulation may have been part of the motive for the metal finishing SGP does not mean that the source reduction and pollution prevention undertaken pursuant to the SGP was a façade. One way to view the metal finishing SGP is as a deal between federal EPA and the metal finishing industry under which EPA agreed to refrain from toughening traditional regulatory requirements in exchange for the industry's promise to pursue source reduction and pollution prevention. By generating 
improved environmental performance while dispensing with many of the costs of a permit-based system such as sampling, inspections, and reporting, such a sectoral environmental contract can generate better environmental performance while greatly lowering administrative costs. To the extent the SGP represented such a win-win situation, the self-interest of the metal finishers in forestalling costly new regulation matched the public interest in reducing the industry's environmental impact at lowest cost.

The most striking example of such a sector-wide agreement generated by the SGP was EPA's RCRA rulemaking regarding the storage of F006 hazardous wastes. EPA's decision to extend the period of time that metal finishers may store F0006 waste on site in exchange for pollution prevention and waste recycling efforts by metal finishers represents a classic instance of the kind of win-win situation that the inefficiency of existing regulation makes possible. In this case, the inefficiency of the status quo regulatory regime, specifically the way in which it forced metal finishers to incur unnecessary waste disposal transportation costs, was the pathway to creating financial incentives for improved environmental performance by metal finishers. Under the new regulation, more liberal on-site waste storage time limits benefit waste finishers' bottom lines, while their commitment to recycling and waste reduction provides the environmental outcomes that are the ultimate goal of RCRA.

The SGP also offered the potential for metal finishing firms in the top two regulatory tiers to signal their commitment to environmental performance to local POTWs in order to continue dealing cooperatively with such regulators. A core aspect of the SGP was the involvement of local POTWs in crafting a new and more flexible 
regulatory environment for firms that met (or began to meet) SGP goals. "Regulatory flexibility" in the SGP meant that state and local regulators would tailor regulatory requirements and enforcement penalties to a particular facility's performance. Under this approach, which may be called "regulatory tiering" (Speir 2001), facilities would be rewarded for participating in the SGP and meeting (or making progress toward) the SGP source and waste reduction goals. Like Project XL and other EPA regulatory reinvention programs of the 1990's, the underlying idea was to make the inefficiency of the existing regulatory structure into a virtue. State or local regulators could agree to reduce some costly but environmentally unproductive regulatory requirements (involving such things as recordkeeping, monitoring for pollutants that were not actually present in wastestreams, and unproductively frequent self-sampling) for those facilities that made progress toward meeting SGP's goals of improved environmental management and performance.

States and municipalities that appear to have been the most active in the SGP program did create regulatory tiers for metal finishers under which the better a company's performance in terms of pollution prevention and reduction, the greater the benefits it would receive. ${ }^{17}$ These benefits were in the form of both technical and financial assistance and regulatory relaxation. Potential regulatory benefits to metal finishers were to be granted by the local POTW's who effectively regulate metal finishers as indirect dischargers. These regulatory benefits consisted primarily of reductions in the required frequency of self-sampling and inspections, with extended and simplified permits offered to metal finishers that achieved the highest level of performance. (See,

\footnotetext{
${ }^{17}$ For examples, see Michigan Metal Finishing Strategic Goals Program 2000:3-4; City of Statesville, N.C. Cooperative Agreement: 3; New York State Strategic Goals Program 2000: 7.
} 
for example, Michigan Metal Finishing Strategic Goals Program 2000: 4; National Metal Finishing Strategic Goals Program 2001: 4; New York State Strategic Goals Program: 2000: 7). In New York City, for example, self-sampling requirements for jewelers were reduced to the federal minimums, as were POTW inspection and monitoring requirements. (Heckler 2000).

Under the SGP, as under other regulatory reinvention initiatives, facilities were not to get regulatory benefits unless they first demonstrated progress toward or achievement of superior environmental performance. Such progress requires a facility or firm to possess both information about potential performance improvements and the capital to make those improvements a reality. As with other sector-based voluntary environmental programs, the metal finishing trade associations cooperated with the federal EPA to produce and distribute information regarding best environmental practices. These trade associations included the American Electroplaters and Surface Finishers, the Metal Finishing Suppliers' Association, and the National Association of Metal Finishers. Through efforts ranging from pollution prevention workshops to free non-enforcement audits, the SGP facilitated efforts by EPA and metal finishing trade associations to produce and widely disseminate information on best environmental practices.

From the economic point of view of both the industry and society at large, there is indeed a strong case for providing such information as a free public good. From the point of view of the industry, the more widely best-practice information is shared and adopted, the better the industry's overall environmental performance, and the lower the probability of costly enforcement actions and new regulations. Moreover, while all firms within a 
sector benefit to some extent when the sector improves its environmental performance, the biggest firms that are most closely watched by regulators and citizen enforcers and that have the financial capability both to pay fines and meet new, tougher standards benefit the most.

Interviews with metal finishing industry representatives confirm that it was the higher-quality, top-tier metal finishers that were pivotal in creating the SGP. ${ }^{18}$ The evidence also shows, however, that the financial and technical assistance offered by the SGP was insufficient to enlist large numbers of the important middle tier firms. The SGP may well have informed many such metal finishers about new and better production and waste management processes, but to succeed on a large scale, the program would have needed to subsidize substantially the investments such changes require.

Indeed, perhaps one of the clearest lessons of the SGP is that regulatory incentives alone will be typically be insufficient to motivate firms to "go beyond compliance." This important point is brought home best by a concrete example. According to local POTW officials interviewed for this study, "compliance" with Clean Water act effluent standards already requires metal finishers to generate very clean wastewater (as one source put it, "very close to meeting drinking water standards"). Further reductions in wastewater effluent (to make the wastewater possibly even suitable for recycling) typically cost on the order of $\$ 75,000$ - $\$ 100,000$. By comparison, even if a POTW reduced the frequency of metal finishers' required self-sampling to federal minima, it would save a metal finisher roughly on the order of $\$ 1000$ - $\$ 5000$ per year (depending

\footnotetext{
${ }^{18}$ The finding that it is larger firms that tend to participate in voluntary programs is quite general. Videras and Alberini (2000) found that larger firms were more significantly more likely to participate in three different EPA voluntary programs -- Waste Wi\$e, Green Lights and 33/50.
} 
upon the status quo sampling frequency). ${ }^{19}$ Given an industry that is already highly regulated, as is the metal finishing industry, reducing pollution "beyond compliance" has high marginal cost. In the metal finishing industry at least, it seems that this cost that generally dwarfed the monetary value of marginal regulatory benefits that state and local regulators were able to offer by reducing regulatory paperwork, sampling, monitoring and inspection burdens.

\section{Should EPA Attempt to Replicate the SGP?}

To think sensibly about whether to try to extend a program such as the metal finishing SGP to other sectors, EPA must answer a question that apparently no one connected with the SGP ever openly asked. This question is whether it is better to try to help an industry of small- and medium-sized firms overcome its environmental management problems, or to instead adopt a regulatory attitude that creates incentives for the consolidation and vertical integration of that industry into firms better capable of managing their environmental impacts. EPA targeted SGP at the small, independent job shops, not at the metal finishing shops that are owned by and located within the plants of large manufacturing firms such as Boeing and General Motors. While EPA puts metal finishing that takes place within such a captive environment in a completely different regulatory category than job shop finishing, from the point of view of the environment and human health what matters is the industrial process, not where it is taking place.

Metal finishing is a process with a very high potential environmental impact. American society will continue to demand declines in this impact. As a number of

\footnotetext{
${ }^{19}$ See also Heckler \& LaGrotta 2000, reporting that reducing the self-sampling frequency for New York
} 
empirical studies have shown (Millimet 2003), pollution prevention and control expenditures increase the minimum efficient scale of facilities. As the experience of the metal finishing SGP confirms, the burden of such costs is often too much for small firms to be able to finance. The natural solution, and the one provided by the market, is for such small firms to disappear and for the large manufacturing firms that have substantial internal and external sources of capital to bear the cost of society's continuing demand for environmental performance improvement.

Regulatory policies that actively encourage firms to integrate vertically and take direct control over environmentally sensitive aspects of their production processes may be relatively rare, but those that do exist are certainly well known. For example, whatever its problems, Superfund's liability regime has completely changed the incentives faced by large chemical and petrochemical companies. Such firms no longer contract out their waste disposal operations to small, undercapitalized disposal firms, but exercise direct control over waste disposal. A similar approach, in this case involving upstream liability for the environmental harms caused by growing animals in warehoused pens, seems the likely solution to the problem of regulating concentrated animal feed operations (CAFOs). Indeed, a very basic economic lesson is that so long as large firms can effectively escape responsibility for the environmental compliance burden associated with a particular stage of their production or distribution by contracting out that stage to smaller outside firms, they will have an incentive to do so. But when the small firms cannot meet those burdens while remaining economically viable, such contracting out effectively eliminates compliance. Small economically stressed firms will usually opt out.

city jewelers saved them an average of $\$ 1000$ per year. 
Most federal environmental statutes do not create a broader liability scheme. In particular, the Clean Water Act, arguably the most significant environmental law for metal finishing, does not utilize liability as a strategy. However, even under this statute, EPA retains substantial discretion. In my view, EPA should exercise that discretion not with a goal of perpetuating inefficiently small and environmentally constrained independent metal finishing job shops, but to create incentives for large manufacturers that now contract their operations out to such firms to internalize those operations and manage them more responsibly. The goal should be to facilitate this economically inevitable and environmentally sound transition by easing the financial costs of such transition to the small job shops.

A model for how to do this already exists: the tradeable quota market that EPA used with such great success in accomplishing the phase-down and eventual elimination of lead additives in gasoline. As described in considerable detail by others (Nichols 1997; Hahn \& Hester 1989), by allowing small refiners to buy lead additive permits from large refiners that had already reduced lead content, EPA's lead phase-down rule allowed small refiners that could not financially comply with the lead additive reduction a period of years over which to continue in business profitably. Because firms that surpassed the goals could sell their unused quotas, EPA's rule also speeded up the achievement of the overall goal of eliminating lead.

Such programs are not always the right way to go. In particular, they are not appropriate when pollution is effectively concentrated in particular "hot spots." Still, they hold enormous potential for easing the transition to new, tougher environmental requirements and a new, vertically integrated metal finishing industry. In my view, 
instead of creating voluntary programs like SGP, EPA's time would be better spent exploring the feasibility of such a tradeable rights regime for metal finishing and similarly structured industries. Rather than developing more voluntary programs, the best strategy to improve environmental management in sectors like metal finishing may be to impose mandatory performance requirements but give firms flexibility to meet them and incentives to surpass them. 


\section{REFERENCES}

Battle, Jackson B. and Maxine L. Lipeles. 1998. Water Pollution. $3^{\text {rd }}$ edition. Cincinnati, Ohio: Anderson Publishing

Boyd, James. 1998. Searching for the Profit in Pollution Prevention: Case Studies in the Corporate Evaluation of Environmental Opportunities. Washington, DC: Resources for the Future.

CA DTSC (California Department of Toxics Substances Control). No date. Metal Plating and Finishing Industry Project Feasibility Overview. http://www.dtsc.ca.gov/pollutionprevention/ppac-metal-plating-report.pdf (accessed December 14, 2004).

Carraro, Carlo and Francois Leveque. 1999. Introduction: The Rationale and Potential of Voluntary Approaches. In Voluntary Approaches in Environmental Policy: 1-15; edited by Carlo Carraro and Francois Leveque. Boston: Kluwer Academic Publishers.

Coglianese, Cary and Laurie K. Allen. 2004. Does Consensus Make Common Sense? Environment 46(1):10-24

Cooperative Agreement between the City of Statesville and [Metal Finishing Company](undated). Available at www.strategicgoals.org/tools/localsgp.htm (last accessed February 2, 2005)

Duke, L. Donald. 1994. Hazardous Waste Minimization: Is it Taking Root in U.S. Industry? Waste Minimization in Metal Finishing Facilities of the San Francisco Bay Area, California. Waste Management 14(1): 49-59. 
, Matthew Buffleben and Lisette A. Bauersachs. 1998. Pollutants in

storm water from metal plating facilities, Los Angeles, California. Waste

Management 18: 25-38.

Gunningham, Neil, Dorothy Thornton and Robert Kagan. 2004. Motivating

Management: Corporate Compliance with Safety, Health and Environmental

Regulation, Australian National University, National Research Centre for OHS

Regulation, Working Paper 30 (September , 2004).

Heckler, Phil and Robert LaGrotta. 2000. SGP - A Municipal Perspective. 30

Clearwaters (available at www.nywea.org/clearwaters/304050) (last accessed February 2, 2005).

Howard, Jennifer, Jennifer Nash and John Ehrenfeld, 2000. Standard or Smokescreen? Implementation of a Voluntary Environmental Code. California Management Review 42(2): $63-82$

Jalley, Elizabeth M., Peter Bryan Moores, Brian L. Henninger and Goud P. Maragani. 2002. Environmental Crimes. American Criminal Law Review 39(1): 403-86

Johnston, Jason Scott. 2005. Signaling Social Responsibility: Signaling Social Responsibility: Law, Activists, and Market Incentives for Corporate Environmental Performance. University of Pennsylvania Law School, Program on Law and the Environment Working Paper No. 05-001.

Johnston, Jason Scott. 2005. Tradeable Pollution Permits and the Regulatory Game, in Thirty Years of Market Based Instruments for Environmental Protection: An Assessment. Jody Freeman and Charles Kolstad, editors. Forthcoming, Oxford University Press. 
Kagan, Robert A. 2005. Environmental Management Style and Corporate Environmental Performance. In Leveraging the Private Sector: ManagementBased Strategies for Improving Environmental Performance. Edited by Cary Coglianese and Jennifer Nash. Washington, DC: Resources for the Future.

Kagan, Robert A., Neil Gunningham, and Dorothy Thornton, 2003. Explaining Corporate Environmental Performance: How Does Regulation Matter? Law and Society Review 37(1): 51-90.

King, Andrew A. and Michael J. Lenox. 2000. Industry Self-Regulation without Sanctions: The Chemical Industry Responsible Care Program, Academy of Management Journal 43(4): 698-716.

Lyon, Thomas P. and John W. Maxwell. 2004. Corporate Environmentalism and Public Policy. New York: Cambridge University Press.

Maxwell, John W., Thomas P. Lyon and Steven C. Hackett. 2000. Self-Regulation and Social Welfare: The Political Economy of Corporate Environmentalism. Journal of Law and Economics 43(2): 583-618.

Michigan Metal Finishing Strategic Goals Program. 2000. Program Description. Available at www.strategicgoals.org/tools/localsgp.htm (last accessed February 2, 2005)

Millimet, Daniel L. 2003. Environmental Abatement Costs and Establishment Size. Contemporary Economic Policy 21: 281-296.

MOEA (Minnesota Office of Environmental Assistance). 1999. Metal Plating and Finishing. http://www.moea.state.mn.us/publications/SIC3471.pdf (accessed February 2, 2005). 
NCMS (National Center for Manufacturing Sciences). 2000. Benchmarking Metal Finishing. Report 0076RE00. June. Washington, DC: NCMS.

National Metal Finishing Strategic Goals Program. 2001. Indiana Implementation Plan for 2001-2002. Available at www.in.gov/idem/strategicgoals/implementation.htm (last accessed February 2, 2005) New York State Strategic Goals Program. 2000. “Metal Finishing” Program Framework, available at www.strategicgoals.org/tools/PDF/Nyframe.pdf (last accessed February 2, 2005)

Nichols, Albert L. 1997. Lead in Gasoline. In Economic Analyses at EPA: Assessing Regulatory Impact, edited by Richard D. Morgenstern. Washington, D.C., Resources for the Future Press.

Nixon, Will. 1998. The Thin Green Line. The Amicus Journal 20(3): 14-16.

Porter, Michael E. 1991. America's Green Strategy. Scientific American 264(4): 168.

Porter, Michael E. and Claas van der Linde. 1995. Toward a New Conception of the Environment-Competitiveness Relationship. Journal of Economic Perspectives 9(4):97-118.

Schwartz, Richard E., Steven P. Quarles and Ellen B. Steen. 1999. Encouraging SelfAudting within the Pork Industry: The Nationwide Clean Water Act Enforcement Agreement for Agriculture's First Industry-Wide Auditing Program, Environmental Law Reporter. 29: 10395-10410.

Segerson, Kathleen and Thomas J. Miceli. 1998. Voluntary Environmental Agreements: Good or Bad News for Environmental Protection? Journal of Environmental Economics and Management 36: 109-130. 
Small, Arthur A. III and Joshua Graff Zivin 2002. A Modigliani-Miller Theory of Corporate Social Responsibility. Mimeo, Columbia University School of International and Public Affairs and Earth Institute. Available to SSRN subscribers at http://papers.ssrn.com/sol3/papers.cfm?abstract_id=325921.

Speir, Jerry. 2001. EMSs and Tiered Regulation: Getting the Deal Right. In Regulating from the Inside: Can Environmental Management Systems Achieve Policy Goals? edited by Cary Coglianese and Jennifer Nash. Washington, D.C.: Resources for the Future Press, 198-219.

Stoll, Richard G. 1989. Coping with the RCRA Hazardous Waste System: A Few Practical Points for Fun and Profit, Environmental Hazards 1: 6-10.

Strategic Goals Program 2001a. 2001 Reports, Summary of Progress Report Performance. http://www.strategicgoals.org/reports2/review2a.cfm?state=all (accessed December 14, 2004). . 2001b. 2001 Reports, Sludge Generation Normalized Using Sales (Based on Dry Solids). http://www.strategicgoals.org/reports2/t5.cfm?state=all (accessed December 14, 2004). .2001c. 2001 Reports, Toxic Organic Chemical Emissions Normalized by Sales. http://www.strategicgoals.org/reports2/t8.cfm?state=all (accessed December 14, 2004). . 2001d. 2001 Reports, Water Discharge Nomalized Using Sales. http://www.strategicgoals.org/reports2/t4.cfm?state=all (accessed December 14, 2004). 
U.S. Census Bureau. 1999. Electroplating, Plating, Polishing, Anodizing, and Coloring: 1997 Economic Census. EC97M-3328C. August. Washington, DC: U.S. Department of Commerce.

U.S. EPA (Environmental Protection Agency). 1980. Proposed Amendments to Final Rules. Electroplating Point Source Category Effluent Guidelines and Standards Pretreatment Standards for Existing Sources. Federal Register 45:45322, July 3. 1994. Sustainable Industry Project. . 1995a. Profile of Metal Fabrication Industry.

http://www.epa.gov/compliance/resources/publications/assistance/sectors/noteboo ks/fabric.html (accessed December 13, 2004).

. 1995b. Proposed Rule. Effluent Limitations Guidelines, Pretreatment

Standards, and New Source Performance Standards: Metal Products and

Machinery. Federal Register 60:28210, May 30.

. 1998. Metal Finishing F006 Benchmark Study, Washington, DC.

. 1999. Common Sense Initiative Metal Finishing Sector Subcommittee

Factsheet.

http://www.epa.gov/ispd/pdf/pubs_csifactsheet.pdf (accessed December 14, 2004).

. 2000. Final Rule. 180-Day Accumulation Time Under RCRA for Waste Water Treatment Sludges From the Metal Finishing Industry. Federal Register 65:12378, March 8. 
. 2001a. Proposed Rule. Effluent Limitations Guidelines, Pretreatment

Standards, and New Source Performance Standards: Metal Products and

Machinery Point Source Category. Federal Register 66:424, January 3.

. 2001b. Living the Vision: Accomplishments of the National Metal Finishing

Strategic Goals Program . EPA 240-R-00-007. January.

. 2002. Notice of Data Availability. Effluent Limitations Guidelines,

Pretreatment Standards, and New Source Performance Standards for the Metal

Products and Machinery Point Source Category. Federal Register 67: 38752,

June 5 .

. 2003. Final Rule. Effluent Limitations Guidelines and New Source

Performance Standards for the Metal Products and Machinery Point Source

Category. Federal Register 68: 25686, May 13.

Videras, Julio and Anna Alberini. 2000. The Appeal of Voluntary Environmental Programs: Which Firms Participate and Why? Contemporary Economic Policy 18(4): 449-461.

Washington State Department of Ecology. 1996. Pollution Prevention Progress for 23 Electroplating Facilities: An Industry Sector Report, Publication No. 96-426 (August). http://www.ecy.wa.gov/pubs/96426.pdf. (accessed December 14, 2004). 